\title{
Efektivitas Model Suction Terbuka dan Tertutup Terhadap Kejadian Pneumonia Pada Pasien Yang Terpasang Ventilator Mekanik (VAP): Systematic Review
}

\author{
Teguh Santoso \& Reni Sulung Utami
}

\section{Intisari}

\begin{abstract}
Latar Belakang: Hisap lendir melalui pipa endotrakeal merupakan prosedur yang paling efektif untuk membersihkan lendir yang menumpuk pada saluran pernapasan pada pasein yang terpasang ventilator. Ada dua macam model hisap lendir, yaitu model hisap lendir terbuka dan tertutup.

Tujuan: Untuk mengetahui efektivitas model hisap lendir terbuka dan tertutup terhadap kejadian ventilator associated pneumonia (VAP) pada pasien yang dirawat diruang intensif (ICU).
\end{abstract}

Metode: Sumber data didapatkan dari PubMed, Ebsco, Proquest, dan Google Scolar periode tahun 2000 sampai dengan 2015 dengan mengunakan kata kunci: suctioning, open suctioning, closed suctioning, ventilator associated pneumonia, dan intensive care unit. Jurnal yang digunakan dalam penelitian ini adalah jurnal yang melakukan perbandingan antara model hisap terbuka dan tertutup, dilakukan pada manusia dengan desain prospektif kohort dan full text.

Hasil: Dari 55 artikel ilmiah yang diidentifikasi hanya 4 yang dilakukan review. Artikel tersebut menjelaskan hubungan pemberian model hisap lendir terhadap kejadian VAP. Dimana dari 4 artikel tersebut seluruhnya menyatakan bahwa tidak ada hubungan signifikan secara statistic.

Kesimpulan: Model hisap lendir terbuka dan tertutup dapat membantu sistem kerja pernapasan dan tidak menimbulkan terjadinya VAP pada pasien yang menggunakan ventilator.

Kata kunci: closed suctioning, intensive care unit, open suctioning, suctioning, dan, ventilator associated pneumonia.

\section{Pendahuluan}

World Health Organization (WHO) tahun 2015 menyebutkan bahwa pneumonia merupakan infeksi akut pada saluran pernapasan terutama pada paru-paru yang disebabkan oleh bakteri atau virus. Ventilator-associated pneumonia (VAP)

\section{Afiliasi Penulis}

1 | Prodi Keperawatan Stikes Guna Bangsa Yogyakarta

2 | Prodi Keperawatan Universitas Diponegoro

Korespondensi kepada

T.Santoso

tg.santoso21@gmail.com adalah pneumonia yang berkembang 48 jam atau lebih setelah pasien diberikan atau dipasang ventilasi mekanis dengan cara menggunakan pipa endotrakeal (ETT) atau trakeostomi (Amanullah, 2013). Di Indonesia kejadian VAP belum dilaporkan secara pasti, namun di luar negeri VAP diperkirakan dapat meningkat 8-28 \% pada pasien dengan bantuan ventilator mekanik (Nency et al, 2015). Faktor resiko VAP adalah kondisi pasien, bronkoaspirasi, infeksi silang, alat terapi pernapasan, penggunaan alat-alat invasif, penggunaan steroid dan endotracheal suction (ES).

Penelitian terdahulu yang dilakukan oleh Zeitoun et al, 2003 menyatakan bahwa hisap lendir pada pipa endotrakeal merupakan salah satu prosedur yang sering dilakukan pada pasien yang 
terpasang alat bantu napas (ventilator). Tindakan tersebut dapat membersihkan lendir yang menumpuk pada saluran trackeobronkeal, meningkatkan proses oksigenasi, mengurangi penumpukan lendir, mencegah terjadinya sumbatan pada pipa endotrakeal, menurunkan kerja napas, mencegah terjadinya ateletaksis, dan infeksi pada sistem pernapasan. Tindakan ES biasanya dilakukan 8-17 kali sehari dan perlu diperhatikan bahwa tindakan tersebut dapat membuat tidak nyaman pasien dan merupakan salah satu tindakan invasive (Jongerden, 2007).

Ada dua jenis atau model hisap lendir yang sering dikenal, yakni model terbuka dan tertutup. Model sistem hisap terbuka dilakukan dengan cara melepas sabungan antara selang ventilator dengan pipa endotrakeal. Pada model sistem hisap tertutup dilakukan sebaliknya, yakni tanpa melepas sambungan antara selang ventilator dan pipa endoktrakeal sehingga oksigen tetap adekuat dan dapat meminimalkan resiko infeksi (Paggoto et al, 2008). Manfaat lain dari model sistem hisap tertutup yakni dapat digunakan selama 24 jam atau lebih pada sambungan ventilator, menghemat biaya perawatan, menurunkan stress psikologi pasien, memiliki resiko yang kecil terhadap kontaminasi silang, serta hipoksemia (Zeitoun et al, 2003). Model sistem hisap tertutup sangat berkembang pada beberapa decade ini. Di Amerika serikat penggunaan model tertutup lebih sering digunakan dibandingkan dengan sistem terbuka, yakni pada kisaran angka $58 \%$ dan $4 \%$, terutama dilakukan di ruang rawat intensif atau yang sering dikenal dengan ICU (Jongerden, 2007).

Tujuan systematic review ini adalah untuk mengetahui efektivitas model hisap lendir terbuka dengan tertutup terhadap kejadian ventilator associated pneumonia (VAP) pada pasien yang menggunakan alat ventilator diruang rawat intensif.

\section{Metode}

Sesuai dengan tujuan artikel, maka literature didapatkan melalui sistem pencarian yang komprehensif (Comprehensive literature search) pada artikel dan jurnal ilmiah periode tahun 2000 sampai dengan 201 dan full text. Pencarian dilakukan pada database internasional seperti
Pubmed, EBSCO, Google Scholar, dan Proquest. Kata kunci yang digunakan dalam pencarian adalah suctioning, open suctioning, closed suctioning, ventilator associated pneumonia (VAP), dan intensive care unit (ICU). Artikel ini menggunakan desain kohort prospektif dengan manusia dengan usia $>13$ tahun sebagai subjek pengamatan dan terpasang alat ventilator lebih dari 48 jam.

Artikel yang telah ditemukan dan dimasukkan dalam penulisan systematic review ini, sebelumnya telah dilakukan penilaian oleh dua independent reviewer dengan menggunakan metode penilaian jurnal ilmiah (critical appraisal). Penilaian jurnal ilmiah yang digunakan adalah Critical Appraisal Skills Program (CASP) yang sebelumnya sudah ddilakukan ektraksi data.

\section{Hasil}

Hasil Identifikasi dan seleksi dari pencarian melalui Pubmed, EBSCO, Google Scholar, dan Proquest didapatkan 55 artikel ilmiah. Dimana 48 artikel yang didaptkan tidak memenuhi kriteria, 7 artikel sesuai dengan yang dicari. Akan tetapi dari 7 artikel tersebut 3 diantaranya merupakan artikel dengan alanalisa sistematik review dan metaanalisis, sehingga pada akhirnya didapatkan 4 artikel penelitian yang masuk dalam review pada artikel ini.

Selanjutnya, setelah dilakukan pemilahan atau seleksi terhadap artikel yang didapatkan maka dilakukan analisa terhadap hasil dari masingmasing artikel yakni hubungan pemberian tindakan model hisap lendir terbuka dan tertutup terhadap kejadian ventilator associated pneumonia (VAP).

\section{Pembahasan}

Hasil review ini adalah untuk mengeneralisasi hasil dari beberapa penelitian $(n=4)$ tentang penggunaan model hisap lendir tertutup dan terbuka terhadap kejadian ventilator associated pneumonia (VAP). Hasil dari beberapa penelitian tersebut $(n=4)$ secara statistik tidak menunjukan adanya hubungan yang bermakna terhadap kejadian VAP pada pasien yang dirawat di ICU rumah sakit. Hal yang sama dikemukakan oleh Maggiore et al., 2002, dalam studinya yang menganalisa beberapa artikel menyatakan bahwa 


\begin{tabular}{|c|c|c|c|c|}
\hline 芯 & $\stackrel{0}{\equiv}$ & $\stackrel{\rho}{=}$ & $\stackrel{\rho}{\equiv}$ & 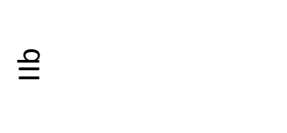 \\
\hline 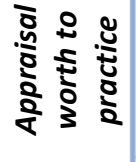 & 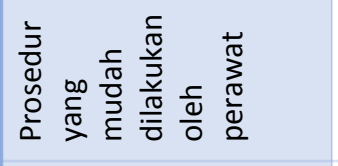 & 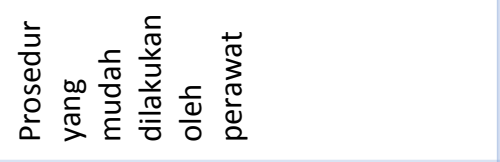 & 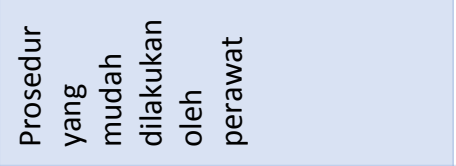 & 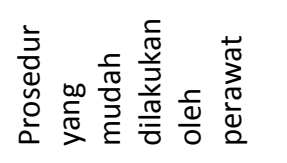 \\
\hline 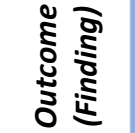 & $\stackrel{Q}{s}$ & $\stackrel{a}{s}$ & $\stackrel{Q}{s}$ & $\stackrel{\hat{k}}{s}$ \\
\hline 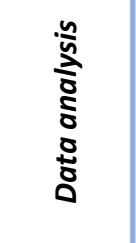 & 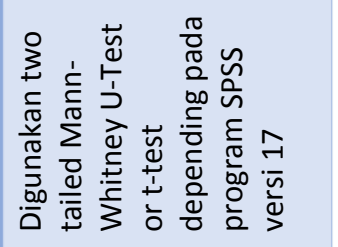 & 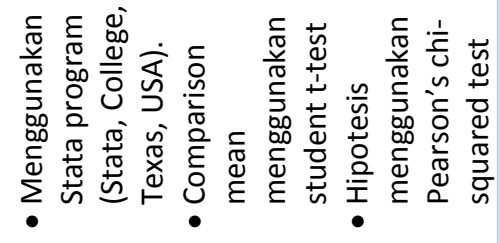 & 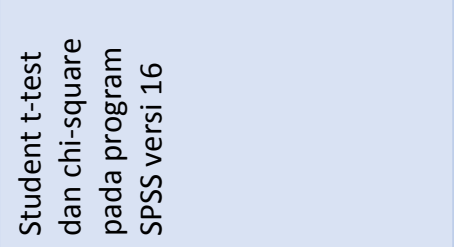 & 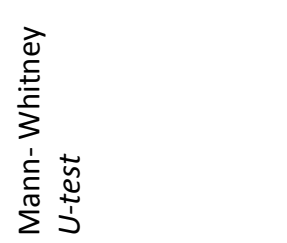 \\
\hline 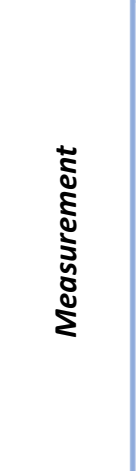 & 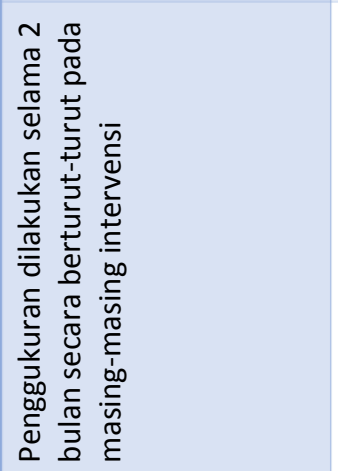 & 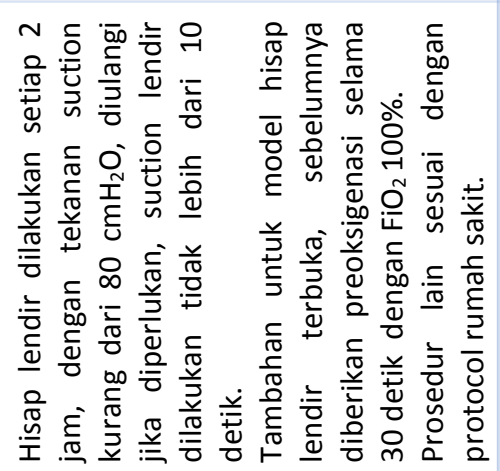 & 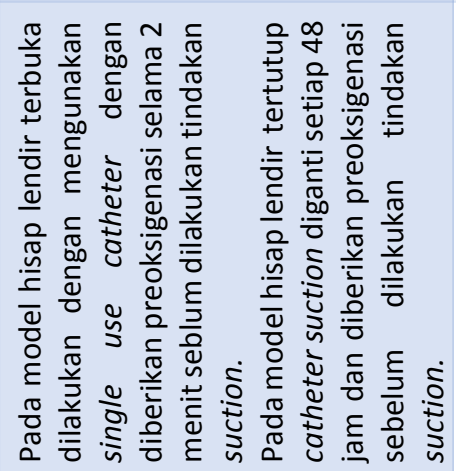 & 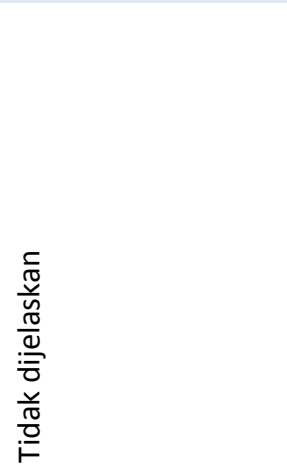 \\
\hline 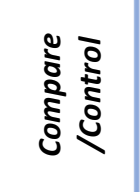 & 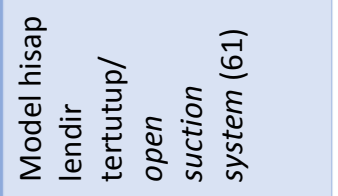 & 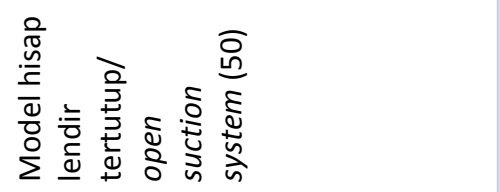 & 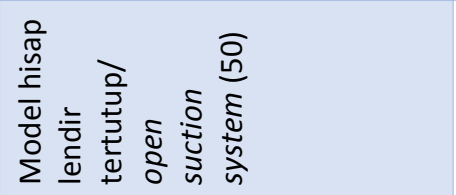 & 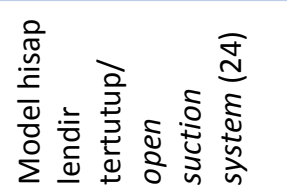 \\
\hline 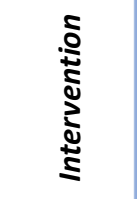 & 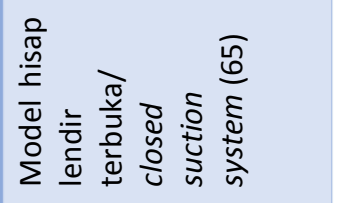 & 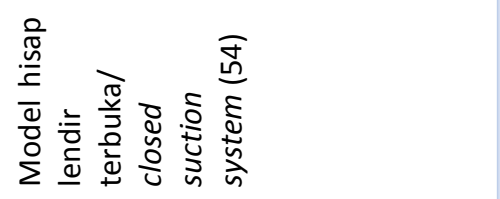 & 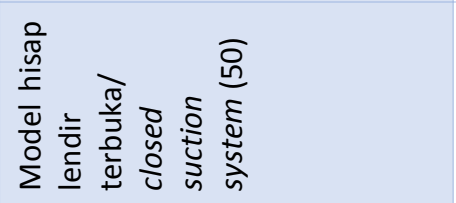 & 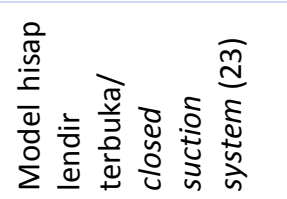 \\
\hline 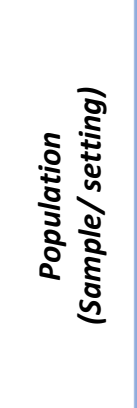 & 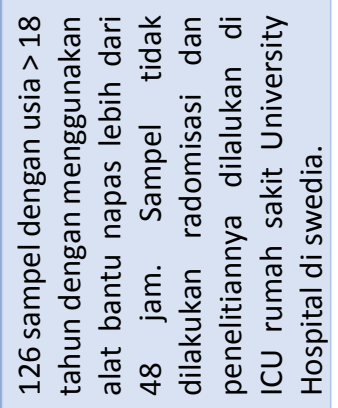 & 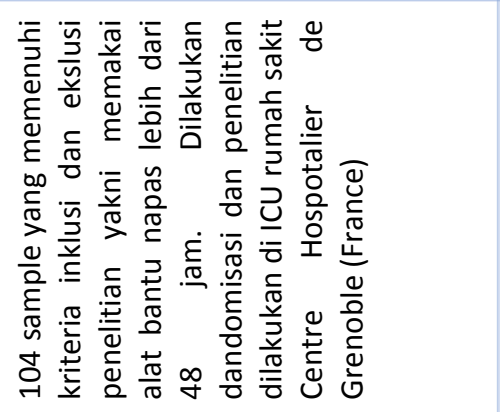 & 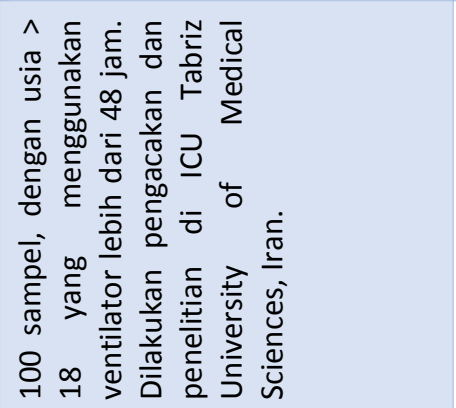 & 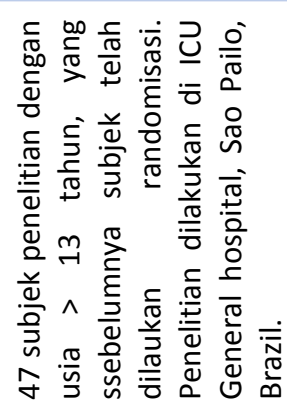 \\
\hline 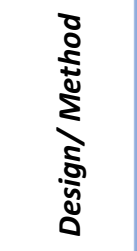 & 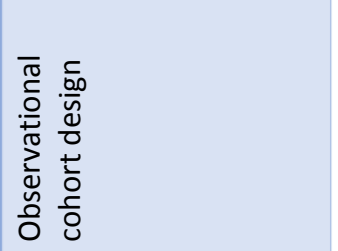 & 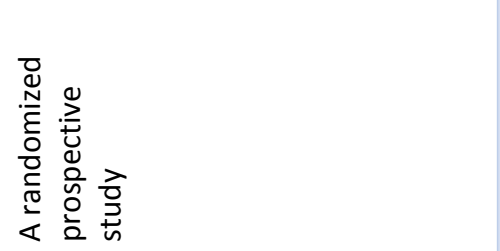 & 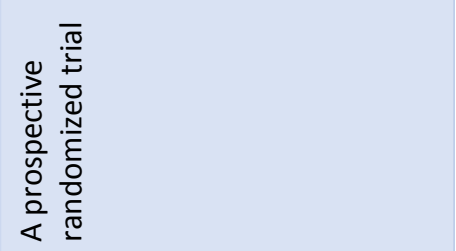 & 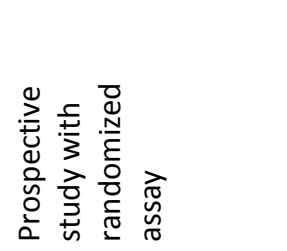 \\
\hline 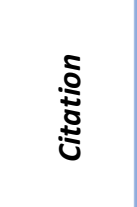 & 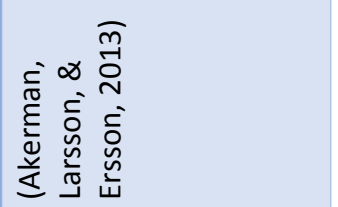 & 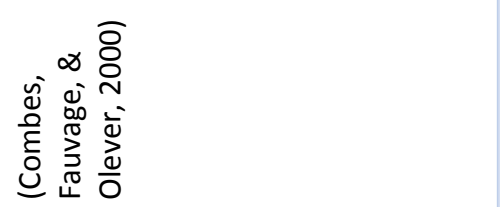 & 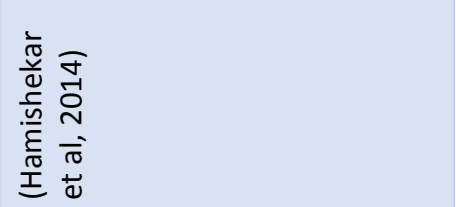 & 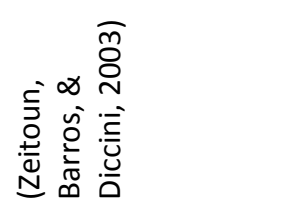 \\
\hline
\end{tabular}




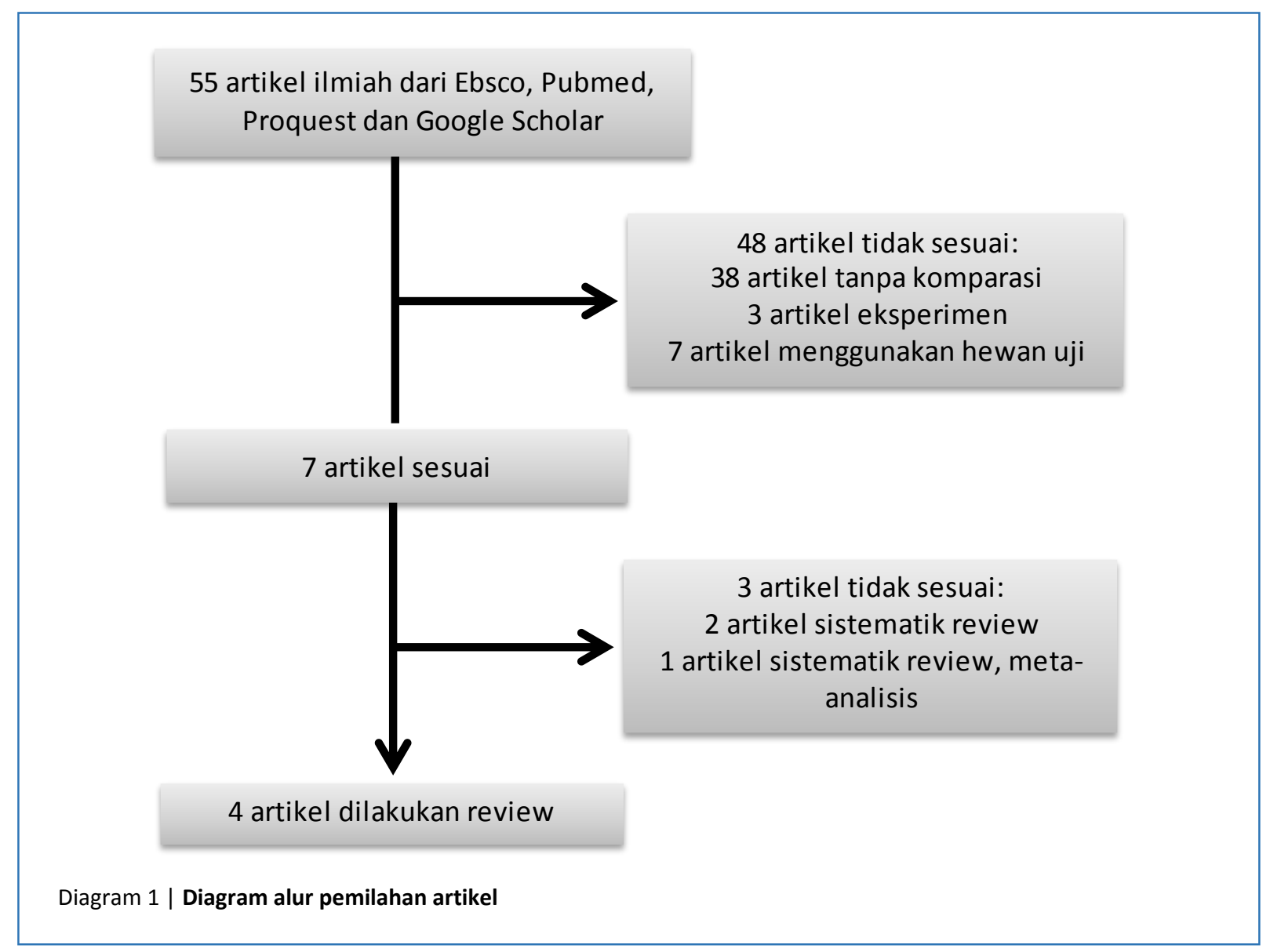

tidak terdapat perbedaan yang signifikan pada pengunaan model hisap lendir. Penyebab utamanya adalah dari proseduran rumah sakit terhadap pasien yang akan diberikan alat bantu napas harus diberikan antibiotik sebelum alat dipasang, sehingga dapat menimbulkan bias pada hasil penelitian. Hasil studi lain yang dilakukan oleh Dodek, Keenan, Cook, \& Heyland pada tahun 2004 menyatakan bahwa pada model hisap lendir terbuka dimana prosedurnya harus melepaskan sambungan sirkuit antara ETT dan selang ventilator sebelum melakukan pengisapan lendir ternyata

Tabel 2 | Perbandingan hasil penelitian tentang tindakan pemberian model hisap lendir terbuka $\&$ tertutup terhadap kejadian VAP.

\begin{tabular}{lcc}
\multicolumn{1}{c}{ Studi } & N & p value \\
\hline (Akerman, Larsson, \& Ersson, 2013) & 126 & $>0.06$ \\
\hline (Combes, Fauvage, \& Olever, 2000) & 104 & $>0.83$ \\
(Hamishekar et al, 2014) & 100 & $>0.27$ \\
\hline (Zeitoun, Barros, \& Diccini, 2003) & 47 & $>0.29$
\end{tabular}

$\mathrm{N}$ : jumlah sampel tidak menimbulkan adanya VAP, begitu juga dengan pengantian kateter suction secara rutin maupun tidak.

Hasil penelitian yang digunakan pada studi ini menggunakan desain kohort secara prospektif dengan 3 penelitian pada sampelnya dilakukan pengacakan dan 1 penelitian tidak. Meskipun telah dilakukan randomisasi, desain tersebut tidak memiliki kualitas evidence yang tinggi (2b) (Moore, 2015). Hal tersebut dikarenakan desain kohor memiliki resiko bias yang tinggi dan membutuhkan subjek penelitian yang cukup banyak (Song \& Chung, 2010).

\section{Kesimpulan}

Penggunaan model hisap lendir terbuka dan tertutup memiliki sejumlah manfaat bagi pasien, seperti menurunkan kerja pernapasan, membantu mengurangi penumpukan lendir didalam saluran pernapasan, dan tidak menimbulkan VAP pada pasien yang dirawat di ICU sehingga aman dilakukan pada pasien membutuhkan alat bantu 
napas. Perawat ICU yang merawat pasien dengan alat bantu napas juga dapat mengunakan kedua model tersebut dalam merawat pasien.

Pada studi ini memiliki keterbatasan seperti pada jumlah sampel yang kurang mencerminkan jumlah populasinya. Yang kedua cara pengukuran data yang berbeda disetiap jurnal yang ditemukan.

\section{Bibliografi}

1. Åkerman, E., Larsson, C., \& Ersson, A. (2014). Clinical experience and incidence of ventilator-associated pneumonia using closed versus open suction-system. Nursing in Critical Care, 19(1), 34-41. http://doi.org/ 10.1111/nicc. 12010

2. Amanulla, Shakeel. (2013). Ventilator-Associated Pneumonia Overview of Nosocomial Pneumonias. diakses tanggal 24 Desember 2015 dari http://emedicine.medscape.com/article/304836-

overview

3. Combes, P., Fauvage, B., \& Oleyer, C. (2000). Nosocomial pneumonia in mechanically ventilated patients, a prospective randomised evaluation of the Stericath closed suctioning system. Intensive Care Medicine, 26(7), 878-82. http://doi.org/10.1007/ s001340051276

4. Dodek, P., Keenan, S., Cook, D., \& Heyland, D. (2004). Clinical Guidelines Evidence-Based Clinical Practice Guideline for the Prevention of. Annals of Internal Medicine, 141, 305-313.

5. Hamishekar, H., Shadvar, K., Taghizadeh, M., Golzari, S. E., Mojtahedzadeh, M., Soleimanpour, H., \& Mahmoodpoor, A. (2014). Ventilator-associated pneumonia in patients admitted to intensive care units, using open or closed endotracheal suctioning. Journal of Anesthesiology and Pain Medicine, 4(5), 1-6. http://doi.org/10.5812/aapm.21649

6. Maggiore, S. M., lacobone, E., Zito, G., Conti, G., Antonelli, M., \& Proietti, R. (2002). Closed versus open suctioning techniques. Minerva Anestesiologica, 68(5), 360-364.

7. Moore, Derek. (2015). Level of Evidence. diakses pada tanggal 26 Desember 2015 dari http://www.orthobullets.com/basic-science/9081/levelof-evidence

8. Paggoto,et al. (2008). Comparison between open and closed suction systems. A systematic review. America, 20(8), 331-338.

9. Song, Jae, W. \& Chung, Kevin, C. (2010). NIH Public Access, 126(6), 2234-2242. http://doi.org/10.1097/ PRS.0b013e3181f44abc. Observational

10. Zeitoun, S. S., de Barros, A. L. B. L., \& Diccini, S. (2003). A prospective, randomized study of ventilator- associated pneumonia in patients using a closed vs. open suction system. Journal of Clinical Nursing, 12(4), 484-9. Retrieved from http:/l www.ncbi.nlm.nih.gov/pubmed/12790861 